\title{
"For me, every child is the whole wide world:" An interview with Naomi Zipori
}

\section{Conducted and translated from Hebrew by Dina Ripsman Eylon, Editor-in-Chief, Women in Judaism: A Multidisciplinary e-Journal}

Naomi [Naama] Zipori has lived in Toronto, Canada for the past thirty years. She's an early childhood educator who has managed a chain of early childhood schools in Israel and Canada. This year, she retired and devotes her time to write two books: one deals with the missing Yemenite children and the other deals with child abuse in early childhood schools. She volunteers with various Jewish organizations and lectures widely about the Yemenite children affair.

Q: When did you and your family arrive in Israel? How was your family's experience?

A: My family arrived in Israel in 1949. We took part in Operation Magic Carpet that many Yemenite Jews awaited for eagerly. My parents took donkeys and she-asses, some belongings and most importantly ancient Torah scrolls and other manuscripts, which were regarded as sacred. The entire immigration process lasted about half a year. My mother was pregnant and when we reached Sana'a, Yemen's capital city, they decided to stay with family until the birth.

My mother gave birth to a son, who was named Zion for their beloved Holy Land. After three months, they decided to continue the journey to the land of Israel. Our economic situation was dire and my parents almost lost hope of fulfilling their dream. A wonderful family offered my parents a loan, which my parents promised to repay after they'd reach their destination.

The journey continued with the donkeys and she-asses carrying the heavy loads. One day, one of the donkeys collapsed from the load but this didn't deter us. The journey took us through extreme heat, forests, and streams, where we washed and collected drinking water. From time to time, we stopped to rest and restore our strength.

In one of the forests, we were attacked by vagabonds who kidnapped some of the children. My parents were enraged and chased them. Once they caught up with them, they managed to pay a ransom for my baby brother Zion. The journey continued but was met with more hardship and starvation. Monkeys attacked us and stole our food supply; many of the other travellers got ill and died. 
Q: What else do you remember from this journey?

A: One day, following months of traveling by foot, relief came as some trucks arrived and drove the people to Aden. We were given food but there was fear that the food was not kosher. Some people claimed that in the Holy Land, jewelry was frown upon. My mother gave them all her magnificent silver jewelry that she received from her parents. Naively, the other travellers surrendered their jewelry to these people. All the holy books, ancient manuscripts and prayer books had to be surrendered too because these people claimed that it would be too heavy for the airplanes to carry. The travellers were promised that all these treasures would be returned to them once they settled in the Holy Land. [This never happened.] The airplane departed and we were all exhausted but full of joy to arrive at our dream land.

Q: Do you remember the landing and first days in Israel?

A: I was eight years old and very anxious about the entire ordeal. When the plane landed, we all stood up and prayed. My grandfather who looked like the prophet Elijah fell to the ground and kissed it. He raised his arms up and proclaimed: "For me, the Messiah arrived." Everyone joined him in prayers, tears of happiness in their eyes.

We were transferred to the Ma'abara [a temporary dwelling] in Rosh Ha'ayin. Every family, regardless of its size, were assigned to a tent. The tents were identical. The new immigrants didn't speak modern Hebrew. They spoke Judeo-Yemeni-Arabic. They didn't complain and accepted life as is. We were given food coupons to buy food at the local grocery store. Life in the tents was difficult; rain filtered through; it was very cold, and we were crowded on metal beds. They gave us clothes, kitchen supplies, oil lamps, and kerosene burners. The sanitary conditions were very harsh. However, my parents showered me and my brother with love and warmth. My father and my grandfather organized prayer and Torah study groups and the mothers tended to domestic needs. 

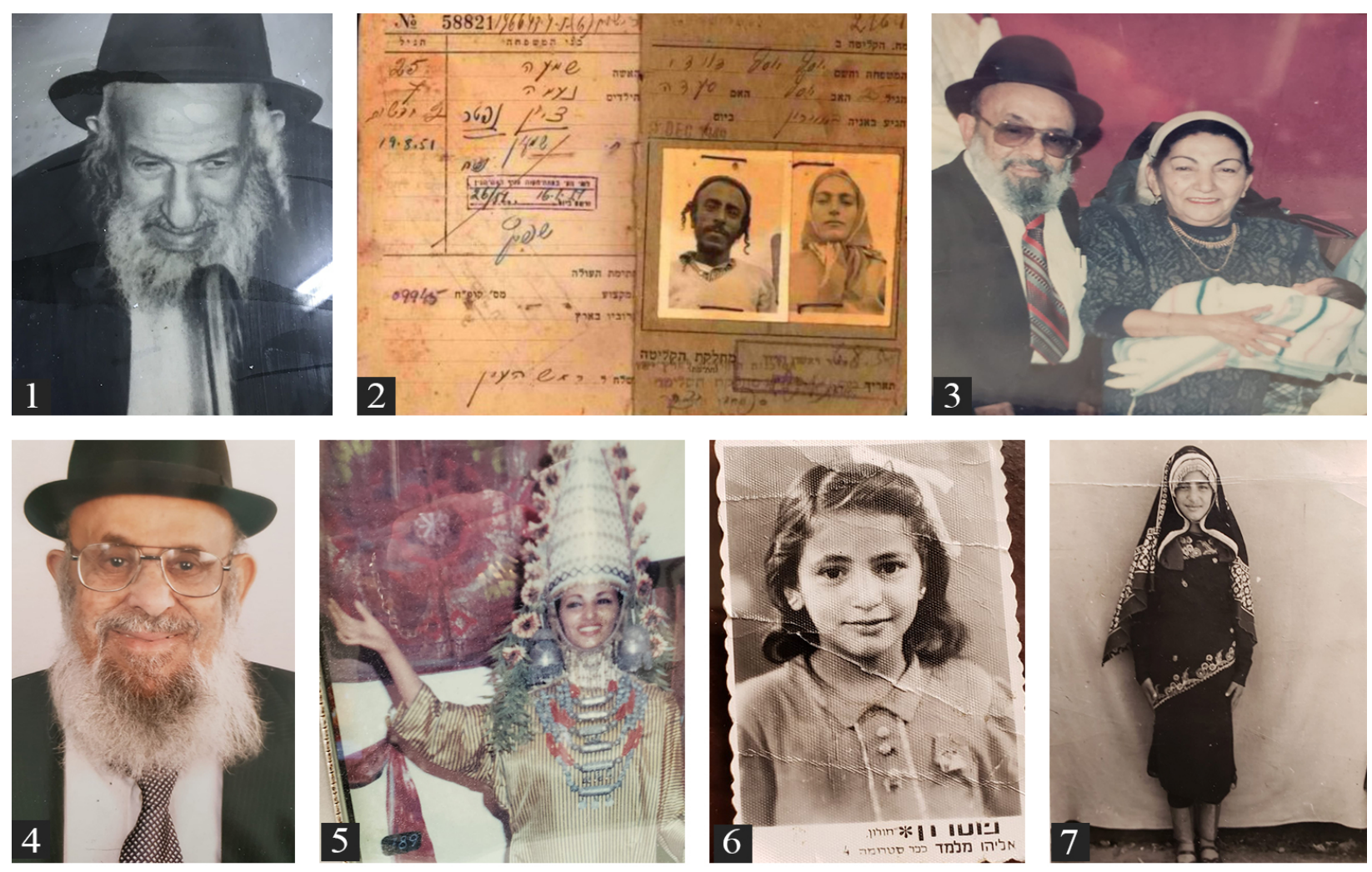

From left to right: 1. Naomi's grandfather, Saadia. 2. Immigration certificate of Naomi's parents. 3. Naomi's parents with a grandson. 4. Naomi's father, Yosef. 5. A Jewish Yemeni bride's traditional jewelry and garments. 6. Naomi on her arrival to Israel. 7. Naomi wearing a holiday outfit. (Images are courtesy of Naomi Zipori.)

Q: How did your brother, Zion, disappeared?

A: In the winter of 1950, unexpectedly, snow covered the country. The cold weather was unbearable and one night I fell off my bed. My mother realized that I wasn't in bed and frantically searched for me. She found me lying outside the tent, frozen. She covered me with whatever she could find and kept me warm.

The following morning, some people who worked for the Jewish Agency for Israel notified us that in order to keep the children safe and warm, they would transfer all the children to the former British barracks, which were nearby. The parents considered it as a good deed with good intention. The mothers were asked to breast feed their babies a few times daily. My brother, Zion, was one of those babies. My mother visited him daily and breast fed him. I often accompanied her on these daily visits. The caregivers were lovely and nice to the hundreds of children who were housed in the barracks. 
Several weeks later, unfamiliar women, distinguishably dressed, began visiting the children. One woman stroked my head; we didn't understand their language and why they visited. They seemed respectable. While making the rounds, they stopped beside some beds and spoke in their foreign language. Trustingly, we assumed that they were concerned about the kids. I remember that my mother told my father that these unfamiliar women were there to care for the children and bring them clothes. This is what they believed to be true...

One morning, my mother's sister dashed hysterically and shouted: "Shoshana, hurry up and pick up Zion. They're loading the kids in boxes and placing them in a car. They say that the kids are ill and they're taking them to the hospital. This isn't right because my daughter, Ziona, is perfectly well. I waited till they were too busy to notice, grabbed Ziona and ran away. Hurry up quickly to get Zion."

My mother ran frantically. My father and I followed. When she reached the barracks with her last breath, Zion was not there. The car was not there. My mother asked the caregivers where Zion was, but they said that he became ill and was taken to the hospital. My parents didn't even know what hospitals were. When they asked for an address, they weren't given any. Then there was an uproar and we learned that hundreds of children were taken like that. There was grief, sorrow and pain everywhere. The parents were very naïve and were not fluent in modern Hebrew. They were literally helpless.

A few days later, when my parents went back to the barracks, they were told that Zion died. My father told my mother that he wouldn't accept this story without seeing Zion's body. "I want to sit Shivah for him," he insisted. My parents didn't receive any answers. But deep down inside they knew that Zion is alive. Days, nights, and years passed and we didn't hear anything about the fate of these missing children. My father and mother always hoped that one day they would meet him. But to no avail.

Q: What did you do in order to search and find Zion, your missing brother?

A: Years passed with endless searches and hopes, but nothing. Meanwhile, I got married. One day while we visited my parents and were reminiscing about Zion, there was a knock on the door. I opened the door and a man presented himself as an army messenger and handed me a draft order for Zion. My parents heard the commotion and hastily came to the door. I calmed my parents, while shaking frenziedly. The man added that if Zion wouldn't comply, he would be summoned 
to court. I told the man that we were notified that Zion passed away in 1950. The man thought that we tried to evade the order. I replied that if he would find Zion, this would be a miracle. He didn't understand what I said, left the order and disappeared. My parents again started to weep in sorrow; yet, they still were hopeful. My father said: "If Zion is conscripted, it means he's alive."

Later on, in meetings with other Yemenite parents, everyone said that they also received the conscription order for their missing children from the Israeli army. The whole affair surfaced again. Hard times. Dedicated organizations, committees of inquiry and investigations were established. The Knesset, the Israeli parliament, founded inquiry commissions. Archives were opened and documents revealed that Yemenite children were sold for adoption; every child was sold for $\$ 5,000$, justified by the claim that the Yemenite Jews had too many children. The parents lived with this horrific pain. Often rumors surfaced but they couldn't be verified.

We visited the Segula cemetery because this is where they claimed that all the dead children were buried. We were hoping to find Zion's grave and many others. Interestingly, all the gravestones were new. At the time, they told us that the children were buried in a mass grave. All of a sudden, there were hundreds of named graves. We demanded from the authorities to exhume the graves to find out if there were any remains, and perform DNA tests. We wanted to know the truth. Despite the fact that most of the parents are deceased now, the brothers and sisters of the missing children are still actively searching for them. I continue to look for Zion, my dear brother; I lecture on the topic and until I discover the truth, I won't be silent.

Q: How did your family and their community deal with the tragedy?

A: My parents and the other immigrants were confused. They didn't want to mourn the missing children and they couldn't accept the terrible consequences. They were sorrowful but continued to searched, aiding each other.

Unemployment was high. We lived in extreme poverty. The children that remained with their parents, age 2 and up, were taken to communal showers; the parents didn't leave them on their own. After the shower, each child received two slices of bread with margarine and four biscuits. The biscuits were a novelty and had a wonderful smell and taste. I always kept a few biscuits to enjoy in the evening. 
Then my parents decided that they need to earn a living to support the family. They worked in the fields using hoes. They were employed in public works projects for the unemployed. This lasted for years in the cold and heat. But they learned to survive in these conditions.

The children were divided into two groups and studied at school in shifts: boys attended from 8$12 \mathrm{pm}$; and girls attended from 12-4pm. I was eight and was assigned to grade one. Learning the new language was tough.

On one occasion, they brought us piles of clothes. Everyone selected some for themselves. Gradually, we acquired the new language. The financial situation deteriorated and women had to join the work force. Many became domestic workers. At the age of eleven, in Petach Tikvah, I also joined the work force as a domestic worker.

My parents had relatives in Tel Aviv and they decided to try their luck there. They rented a place near Shuk Ha'carmel. The place had a yard, which was shared by three families; the washrooms and kitchen were also shared. My father found employment and my mother gave birth to another son. I had to return to work. Yet, my will to further my education was strong and I attended night school. We heard that we can get better housing in Rosh Ha'ayin (where we initially settled); so, my family returned to the town.

We were always hopeful to find Zion, see him on the street one day... All the parents of the missing children felt the same.

Years later, we moved to Jaffa. I graduated from night school and found work as a teacher assistant in kindergarten. My father worked for Rasco (a building company) and slowly our financial situation improved. We then moved to Ramat Gan. My father always dreamed of founding a synagogue. Indeed, he used an existing synagogue to teach Torah. He divided his day between his day job and teaching children and adults in the afternoons and evenings. (In Ramat Gan, we received the conscription order for Zion.)

For years, I've been lecturing about the affair with the hope that one day I'll find my missing brother, Zion.

Once, in an interview on the Israeli TV channel in Toronto, a man called me and said that he found his family through the DNA database of the Yemenite Jews. However, despite taking the DNA test, so far, I haven't found Zion.

Women in Judaism: A Multidisciplinary e-Journal Volume 17 Number 2 (2020) ISSN 1209-9392 
The desire and yearnings to find Zion were immense. Working as a teacher's assistant help me cope with the tragedy. I decided that this would be my career path. It was probably imbedded in my subconscious. I graduated from teacher's college and opened my own kindergarten. For me, every child is the whole wide world. Every child is an angel; every hug, smile and gesture fill me with longings and love. I often ponder over this atrocious affair of the missing Jewish children from Yemen, the Balkan and other eastern countries.

\section{Suggested Resources:}

MyHeritage offers a DNA database of Yemenite Jews:

https://www.myheritage.com/ethnicities/yemenite-jewish/ethnicity-worldwide-distribution

The New York Times features a comprehensive account on the Yemenite Missing Children:

https://www.nytimes.com/2019/02/20/world/middleeast/israel-yemenite-children-affair.html

The Center for Jewish History features a collection on Yemenite Jews:

https://archives.cjh.org/repositories/4/resources/191

Project Gutenberg Self-Publishing Press features an open-source e-book on the history of Yemenite Jews:

http://self.gutenberg.org/articles/eng/Yemenite_Jews

The Association of Jewish Studies Podcasts offers a session on the Yemenite Missing Children: https://www.associationforjewishstudies.org/publications-research/adventures-in-jewish-studiespodcast/the-yemenite-children-affair-and-the-story-of-the-mizrahi-jews-in-the-development-of$\underline{\text { the-state-of-israel-transcript }}$ 